\title{
Crop Response to Soil Acidity Factors in Ultisols and Oxisols in Puerto Rico. XIV. Plantains and Bananas $^{1,2}$
}

\author{
José Rodríguez-García, Edmundo Rivera and Fernando Abruña ${ }^{3}$
}

\begin{abstract}
The effect of soil acidity factors on yield components and leaf composition of plantains and bananas were studied on two Ultisols and one Oxisol. Both crops were extremely tolerant to soil acidity factors on all soils. On the Ultisols, plantains produced similar yields although $\mathrm{pH}$ varied from 4.1 to 6.0 , and exchangeable Al contents from 0 to over $70 \%$ of the cation exchange capacity. On the Oxisol, similar yields were produced when $\mathrm{pH}$ varied from 4.25 to 5.25 , and exchangeable Al contents from 0 to $48 \%$. Soil acidity did not affect bunch weight or number or weight of fruits. Foliar composition was not affected except that $\mathrm{Ca}$ content decreased as acidity of the Ultisols increased. Similarly, bananas produced high yields of marketable fruit at all levels of soil acidity and none of the yield components were affected by the soil acidity factors. Foliar composition was not affected except that Ca content decreased with increasing acidity.
\end{abstract}

\section{INTRODUCTION}

Plantains and bananas are important food crops throughout tropical and subtropical areas of the world. Plantains are mainly consumed as a vegetable, whereas bananas are consumed either as a vegetable or as a fruit in the tropical countries and as a fruit in the temperate regions.

There is little and contradictory information available on the response to liming of bananas and plantains growing on acid Ultisols and Oxisols typical of vast areas of the humid tropics. Pérez-Escolar and Lugo-López (9) studied the effect of soil acidity factors in an Ultisol on plantain yields and found no correlation between yields and soil acidity factors, except for a weak correlation $(r=0.47)$ between $\mathrm{pH}$ and number of fruits per bunch. Bhangoo and Karon (2) working with Giant Cavendish bananas reported a significant increase in bunches cut per acre when dolomitic limestone was applied to acid ( $\mathrm{pH} 4.0$ ) or mildly acid $(\mathrm{pH} 6.0)$ soils. This effect was probably a response to $\mathrm{Mg}$ rather than to liming. Cumba and Fraga (4) working in São Paulo, Brazil, found no response to liming when soil pH ranged from 5.2 to 6.0. Similarly, Gregory (5) and Osborne (8) report no beneficial effect on banana yields due to liming

${ }^{1}$ Manuscript submitted to Editorial Board August 3, 1984.

${ }^{2}$ This paper covers work carried out cooperatively between the Agricultural Research Service, USDA, and the Agricultural Experiment Station, College of Agricultural Sciences, Mayagüez Campus, University of Puerto Rico.

${ }^{3}$ Assistant Agronomist, Agricultural Experiment Station, College of Agricultural Sciences, Mayagüez Campus, University of Puerto Rico; Agronomist and Soil Scientist, Agricultural Research Service, USDA. 
acid soils in Jamaica. On the other hand, Groucher and Mitchell (6), also working in Jamaica, reported a beneficial effect of lime applied to slightly acid soils which were low in $\mathrm{K}$.

The present study determined the response of plantains and bananas to liming and the relationship between the soil acidity factors and yield components, and foliar composition of these crops on two Ultisols and one Oxisol.

\section{MATERIALS AND METHODS}

The experiments were carried out over 2 consecutive years in plots with widely varying levels of soil acidity resulting from differential applications of calcitic limestone over a period of years prior to these experiments.

The experiments were carried out on Corozal clay (Aquic Tropudults), Corozal clay subsoil (topsoil removed), and Coto sandy clay (Tropeptic Haplorthox). There were $304 \times 4 \mathrm{~m}$ plots on each of the Ultisols and 42 on the Oxisol. The plots were surrounded by 15 -cm-deep ditches to prevent runoff from one plot into another.

All plots were planted to plantains of the Maricongo cultivar at $2 \times 2$ $\mathrm{m}$ in February 1981 with corms weighing around $1.5 \mathrm{~kg}$. All plots received $3 \mathrm{t} /$ ha of 10-5-20 fertilizer containing $135 \mathrm{~kg}$ of $\mathrm{Mg}$ and $15 \mathrm{~kg}$ of a mixture of minor elements divided in four equal applications at planting and 4, 7 and 10 months later. Insects and nematodes were controlled by the application of $25 \mathrm{~g}$ of Temik $10 \mathrm{G} /$ plant at planting time and every 3 months thereafter. Plants were sprayed every 21 days with orchard oil to control Sigatoka leaf disease. Plots were maintained free of weeds by periodic hoeing. The bunches were harvested when they attained maturity, from 14 to 17 months after planting.

All plots on the two Ultisols were planted to bananas of the Gran Naine variety in July 1982, with corms weighing around $1 \mathrm{~kg}$ planted at $2 \times 2 \mathrm{~m}$. All plots were fertilized with $1.5 \mathrm{t} / \mathrm{ha}$ of $10-5-30$ containing 135 $\mathrm{kg}$ of $\mathrm{Mg}$ and $15 \mathrm{~kg}$ of a mixture of minor elements divided into five equal applications at 1, 3, 5, 7 and 9 months after planting. Insects and diseases were controlled with the same pesticides as for plantains. Bunches were harvested when they were three quarters full.

For both crops the third leaf was sampled 7 months after planting and analyzed for $\mathrm{N}$ by the Kjeldahl method; $\mathrm{P}$, colorimetrically as molybdate; $\mathrm{K}$ by flame photometry; $\mathrm{Ca}$ and $\mathrm{Mg}$ by the Versenate method (3); and Mn colorimetrically as permanganate.

The soil in each plot was sampled at planting by means of 10 borings at 0 to $15 \mathrm{~cm}$ depth. The samples were air dried and passed through a 10-mesh screen. Exchangeable bases $(\mathrm{Ca}, \mathrm{Mg}, \mathrm{K})$, were extracted with $N$ $\mathrm{NH}_{4} \mathrm{OAc}$ at $\mathrm{pH} 7.0$, and $\mathrm{Ca}$ and $\mathrm{Mg}$ were determined by the Versenate 
method (3), and $\mathrm{K}$ by flame photometry. Exchangeable $\mathrm{Al}$ was extracted with $N \mathrm{KCl}$ and determined by the double titration method (7). Aluminum saturation percentage was determined by dividing the exchangeable Al by the sum of exchangeable $\mathrm{Ca}, \mathrm{Mg}, \mathrm{K}, \mathrm{Al}$, and $\mathrm{H}$. Soil reaction was measured with a glass electrode $\mathrm{pH}$ meter with a 1:1.5 soil-to-water ratio.

Yield components and foliar composition were related to soil acidity factors through regression analysis.

\section{RESULTS AND DISCUSSION}

\section{PLANTAINS}

Soil acidity factors had no effect on yield components or foliar composition of plantains growing in the two Ultisols or the Oxisol (table 1). In the Ultisols, yields averaged close to $30 \mathrm{t} / \mathrm{ha}$ with about $40 \mathrm{fruit} / \mathrm{bunch}$ weighing about $280 \mathrm{~g}$ each at soil $\mathrm{pH}$ ranging from 4.1 to about 6.0 , and exchangeable $\mathrm{Al}$ from 0 to over $70 \%$ of the cation exchange capacity.

Chemical composition of the leaves was not affected by variations in soil acidity (table 1) except for a tendency of Ca content to decrease with increasing acidity.

In the Coto soil (Oxisol), yields and yield components were similar when $\mathrm{pH}$ ranged from 4.25 to 5.25 and exchangeable $\mathrm{Al}$ from 0 to $67 \%$ of the cation exchange capacity (table 1). Yield components were not affected by soil acidity factors. Neither was foliar composition affected by soil acidity except for a tendency of $\mathrm{Ca}$ content to decrease with increasing acidity (table 1).

In the Coto soil, plantain leaves had more than four times the Mn content than those of plantain grown in the Corozal soils (table 1). The higher absolute exchangeable Al values in the Corozal and the higher $\mathrm{Mn}$ content in the Coto may be responsible for these differences.

Plantain yields in the Coto soil were similar to those obtained in the Corozal soil and subsoil.

Plaintains apparently can tolerate very high levels of both $\mathrm{Al}$ and $\mathrm{Mn}$ in the soil and take up $\mathrm{Mn}$ in quantities that will represent toxic levels in other crops.

\section{BANANAS}

Bananas were grown only in the Corozal Ultisols. Bananas were extremely tolerant to soil acidity, producing high yields at acidity levels varying from $\mathrm{pH} 3.7$ to 5.9 with exchangeable $\mathrm{Al}$ from 0 to $76 \%$ of the effective CEC of the soil. The marketable yields, averaging over $55 \mathrm{t} / \mathrm{ha}$, bunch weight, fruits per bunch and hands per bunch were not affected by soil acidity levels (table 2).

Total marketable yield of both plantains and bananas were similar in both the Corozal clay soil and subsoil. 
TABLE 1.-Effect of soil acidity factors on yield components and foliar composition of the Maricongo cultivar of plantains grown in two Ultisols and one Oxisol

\begin{tabular}{|c|c|c|c|c|c|c|c|c|c|c|c|c|}
\hline \multicolumn{3}{|c|}{ Soil acidity factors } & \multicolumn{4}{|c|}{ Yield components } & \multicolumn{6}{|c|}{ Foliar composition } \\
\hline $\mathrm{pH}$ & $\begin{array}{l}\text { Al } \\
\text { sat. }\end{array}$ & $\begin{array}{l}\text { Ca } \\
\text { sat. }\end{array}$ & $\begin{array}{l}\text { Yields of marketable } \\
\text { fruits }\end{array}$ & Fruit/bunch & Bunch weight & Fruit weight & $\mathrm{N}$ & $\mathrm{P}$ & $\mathrm{K}$ & $\mathrm{Ca}$ & $\mathrm{Mg}$ & $\mathrm{Mn}$ \\
\hline & $\%$ & $\%$ & t/ha & No. & $\mathrm{kg}$ & $\mathrm{g}$ & $\%$ & $\%$ & $\%$ & $\%$ & $\%$ & $\mathrm{p} / \mathrm{m}$ \\
\hline \multicolumn{13}{|c|}{ Corozal clay (Aquic Tropudults) } \\
\hline 5.80 & 0 & 68 & 29.6 & 40.5 & 12.4 & 305 & 3.30 & .20 & 4.00 & .64 & .30 & 237 \\
\hline 4.90 & 9 & 66 & 28.9 & 41.4 & 12.1 & 293 & 3.35 & .23 & 3.97 & .64 & .30 & 402 \\
\hline 4.80 & 23 & 56 & 29.6 & 42.0 & 12.4 & 291 & 3.46 & .23 & 3.70 & .68 & .30 & 373 \\
\hline 4.70 & 37 & 40 & 27.7 & 40.6 & 11.6 & 287 & 3.40 & .21 & 3.69 & .60 & .29 & 379 \\
\hline 4.50 & 53 & 33 & 30.1 & 41.6 & 12.6 & 304 & 3.41 & .21 & 3.65 & .57 & .28 & 250 \\
\hline 4.20 & 64 & 24 & 27.7 & 41.9 & 11.6 & 278 & 3.43 & .24 & 3.84 & .53 & .25 & 293 \\
\hline 4.10 & 77 & 13 & 27.7 & 40.4 & 11.6 & 288 & 3.76 & .21 & 4.36 & .51 & .30 & 280 \\
\hline \multicolumn{13}{|c|}{ Corozal clay subsoil (Aquic Tropudults) } \\
\hline 6.00 & 0 & 72 & 25.8 & 39.1 & 10.8 & 276 & 3.38 & .21 & 3.85 & .61 & .39 & 145 \\
\hline 4.90 & 11 & 64 & 26.8 & 39.4 & 11.2 & 285 & 3.31 & .21 & 3.97 & .64 & .29 & 176 \\
\hline 4.70 & 24 & 54 & 29.9 & 40.6 & 12.5 & 307 & 3.30 & .21 & 3.79 & .56 & .33 & 123 \\
\hline 4.60 & 34 & 47 & 28.0 & 41.0 & 11.7 & 285 & 3.29 & .23 & 3.70 & .55 & .31 & 160 \\
\hline 4.40 & 53 & 31 & 29.6 & 40.8 & 12.4 & 329 & 3.31 & .20 & 3.97 & .47 & .28 & 208 \\
\hline 4.10 & 73 & 13 & 26.1 & 38.9 & 10.9 & 280 & 3.44 & .21 & 4.07 & .52 & .24 & 276 \\
\hline \multicolumn{13}{|c|}{ Coto sandy clay (Tropeptic Haplorthox) } \\
\hline 5.25 & 0 & 67 & 31.3 & 43.1 & 13.1 & 305 & 4.04 & .21 & 2.44 & .72 & .42 & 1345 \\
\hline 4.90 & 7 & 65 & 27.0 & 39.3 & 11.3 & 288 & 4.05 & .20 & 2.54 & .82 & .41 & 1370 \\
\hline 4.75 & 17 & 53 & 29.6 & 42.2 & 12.4 & 295 & 3.87 & .21 & 2.72 & .77 & .43 & 1368 \\
\hline 4.55 & 27 & 47 & 27.7 & 42.3 & 11.6 & 275 & 3.98 & .21 & 2.53 & .71 & .40 & 1364 \\
\hline 4.35 & 36 & 45 & 28.7 & 42.7 & 12.0 & 280 & 3.93 & .21 & 2.73 & .70 & .41 & 1429 \\
\hline 4.25 & 48 & 35 & 27.7 & 41.1 & 11.6 & 283 & 4.02 & .21 & 2.52 & .70 & .40 & 1472 \\
\hline
\end{tabular}


TABLE 2.-Effect of soil acidity factors on yield components and foliar composition of the Gran Naine variety of bananas grown in two Ultisols

\begin{tabular}{|c|c|c|c|c|c|c|c|c|c|c|c|c|}
\hline \multicolumn{3}{|c|}{ Soil acidity factors } & \multicolumn{4}{|c|}{ Yield components } & \multicolumn{6}{|c|}{ Foliar composition } \\
\hline $\mathrm{pH}$ & $\mathrm{Al}$ sat. & Ca sat. & $\begin{array}{c}\text { Marketable } \\
\text { yields }\end{array}$ & Fruit/bunch & Bunch weight & Hands/bunch & $\mathrm{N}$ & $\mathrm{P}$ & $\mathrm{K}$ & $\mathrm{Ca}$ & $\mathrm{Mg}$ & $\mathrm{Mn}$ \\
\hline & $\%$ & $\%$ & t/ha & No. & $\mathrm{kg}$ & No. & $\%$ & $\%$ & $\%$ & $\%$ & $\%$ & $\mathrm{p} / \mathrm{m}$ \\
\hline 5.45 & 0 & 69 & 55.8 & 111 & 18.9 & 7.7 & 3.32 & .23 & 3.05 & .45 & .29 & 192 \\
\hline 4.90 & 10 & 61 & 58.2 & 114 & 19.7 & 7.7 & 3.18 & .26 & 2.94 & .49 & .29 & 310 \\
\hline 4.65 & 23 & 42 & 58.7 & 112 & 19.9 & 7.2 & 3.24 & .24 & 2.91 & .45 & .32 & 210 \\
\hline 3.80 & 73 & 12 & 55.1 & 110 & 18.6 & 7.4 & 3.34 & .24 & 2.86 & .31 & .23 & 133 \\
\hline \multicolumn{13}{|c|}{ Corozal clay subsoil } \\
\hline 5.90 & 0 & 69 & 62.8 & 117 & 21.2 & 7.8 & 3.44 & .25 & 3.25 & .45 & .30 & 132 \\
\hline 4.90 & 10 & 55 & 59.7 & 110 & 20.2 & 7.3 & 3.61 & .24 & 2.96 & .41 & .30 & 125 \\
\hline 4.70 & 22 & 48 & 56.6 & 110 & 19.2 & 6.9 & 3.44 & .24 & 3.20 & .42 & .32 & 120 \\
\hline 4.50 & 35 & 32 & 58.2 & 109 & 19.7 & 7.3 & 3.30 & .23 & 2.97 & .37 & .29 & 120 \\
\hline
\end{tabular}


Leaf composition was not significantly affected by soil acidity except for Ca content, which tended to decrease with increasing acidity.

The tolerance of plantains and bananas to soil acidity is much greater than that of tolerant root crops such as cassava and sweetpotatoes (1).

\section{RESUMEN}

Se estudió el efecto de grados de acidez sobre la producción de plátanos de la variedad Maricongo y guineos de la variedad Grand Naine en dos Ultisol y un Oxisol.

En los Ultisol se lograron producciones similares de plátanos a valores de $\mathrm{pH}$ que variaron de 4.1 a 6 y saturaciones del complejo coloidal con Al que fluctuaron entre 0 y $70 \%$. En el Oxisol la producción fue similar a pesar de que el pH varió de 4.25 a 5.25 y la saturación con aluminio cambiable de 0 a $48 \%$. Los factores de acidez no modificaron ni el peso de los racimos ni el número de frutas por racimo. Tampoco se afectó la composición química de las hojas, excepto que el contenido en calcio disminuyó según aumentó la acidez en los Ultisol.

Los guineos produjeron altos rendimientos de fruta comercial en todos los grados de acidez. Estos no afectaron los componentes del rendimiento. El grado de acidez no afectó la composición química de las hojas, excepto que el contenido en calcio disminuyó según aumentó la acidez.

\section{LITERATURE CITED}

1. Abruña-Rodríguez, F., J. Vicente-Chandler, E. Rivera and J. Rodriguez, 1982. Effect of soil acidity factors on yields and foliar composition of tropical root crops, Soil Sci. Soc. Am. J. 46: 1004-007.

2. Bhangoo, M. S. and M. L. Karon, 1962. Investigations on the Grand Cavendish banana. II. Effect of minor elements and dolomitic lime on fruit yields, Trop. Agric. Trin. 39: 203-10.

3. Cheng, K. L. and R. H. Bray, 1951. Determination of calcium and magnesium in soil and plant material, Soil Sci. 72: 449-58.

4. Cumba, J. F. and C. J. Fraga, 1963. Efeito da adubação mineral, orgânico e calagem na produção da bananeira en várzea litorânea de Caragutatuba, Estado de São Paulo, Bragantia 22: 159-68.

5. Gregory, E. J., 1954. Investigations, Bull. 53. Dep. Sci. Agric, Jamaica.

6. Groucher, H. H. and W. K. Mitchell, 1940. Fertilizer investigations with Gros Michel bananas, Bull. 19, Dep. Sci. Agric. Jamaica.

7. McLean, E. O., 1965. Aluminum. In Methods of Soil Analysis, Am. Soc. Agron., Agron. Series No. 9: 994-96.

8. Osborne, R., 1953. Liming experiments with Lacatan bananas Inv. Bul. Ministry Agric. Lands., Jamaica 53: 113-14.

9. Pérez-Escolar, R. and M. Lugo-López, 1979. The effect of soil pH and related acidity factors on yields of plantains (Cv Maricongo) grown on Los Guineos clay, an Ultisol, J. Agric. Univ. P.R. 63 (1) 22-6. 